\title{
REVIEW | Making Aboriginal Men and Music in Central Australia
}

\author{
Åse Ottosson
}

London: Bloomsbury, 2016

ISBN 9781474224628 (HB)

\author{
Ann Werner \\ Södertörn University \\ ann.werner@sh.se
}

Gender and issues in ethnicity, race and indigeneity are integral to music cultures, but seem surprisingly seldom addressed critically in ethnomusicology (Chuse 2003). Independent of genre and location, ethnography focusing on structures of power and questions of identity and difference can focus on British punk as well as Sámi rap. In a new monograph, Åse Ottosson addresses aboriginal music culture and masculinity in central Australia, focusing on aboriginal rock, country and reggae by musicians originating from the desert region of the Northern Territory, Australia. Research conducted in the central Australian desert that addresses music culture and gender, as well as indigenous and First Nation identity is scarce. In other locations research questions on gender, music and indigenous identity have been addressed as interlinked: for example, by wellknown scholars like Beverley Diamond (2000) and Tina K. Ramnarine (2013) exploring gender, femininity and indigeneity in First Nations of Canada and Sámi musics.

One, of many, interesting contributions in Making Men and Music in Central Australia is the discussion of the diversity within Aboriginal music culture, in particular the different musical practices that are evident in various regions of Australia. The music and musicians, their studio work, touring, performances and backstage practices are mapped within Ottosson's detailed ethnography, and their way of making music is contrasted with Aboriginal music cultures from the top 
end of the Northern Territory, and from South-East Australia. Top End music, according to Ottosson, often blends ancestral song styles, instruments and body painted dances with global rock, country, pop and reggae music. By contrast, the Aboriginal music from the South East foregrounds political messages, anti-racism and land rights, sometimes through spirituality, as central to musical practises. In Ottosson's own material on Aboriginal desert music, neither hybridization of new and old, nor politics, are central to the music making process. Rather, the musicians perceive themselves as practicing real and authentic country, rock and reggae, and as being men and musicians in line with what is ordinary (as well as preferred) in their cultural context. This discussion of the ordinary is important as previous studies of popular music and indigeneity often focus on hybridization, or political messages, or both. Her contribution to the research field is also unique in terms of the focus on masculinity, as well as in her mapping of the region Central Australia.

Ottosson's informants state that they don't have to perform their traditions, or be angry activists, on which Ottosson comments that these practices resonate poorly with their gendered ideals of being laid back, grounded, Aboriginal men, showing that the gendered musical practises they engage in are much more complex and contradictory than what was claimed. Using the term "mongrel", Ottosson, shows the borrowing and transformations of music taking place in the practices of these musicians as ongoing. Her ethnographic fieldwork descriptions are fine examples of how music culture develops, resonating with contemporary ethnomusicological research and anthropological methodology.

Theoretically, the author aims to develop the concept of "intercultural mediation" in order to understand how music and identity takes form. When the concept is first discussed she defines intercultural as not only an engagement between indigenous and non-indigenous domains, but also engagements within Aboriginal culture. "Mediation" refers here to the production and experiences of (for example) indigeneity and masculinity. The mediation connects identity practices to global musical, religious and professional domains. Curiously, the role of power, discourse or materiality is not discussed in-depth by Ottosson, who later on compares her way of using the notion of intercultural mediation to Judith Butler's theories on identity as performativity, a theoretical framework central for gender studies, dealing with structures of power versus identity practices, and discourse versus materiality in the construction of gender and sexuality (Butler 1990, 1993). The danger of this omission is that the inequalities and power plays in the music culture in question, as well as structural discrimination, discourses of racism and sexism in Australia, disappear from view. Ottosson's discussion of intercultural mediation seems theoretically under-developed when put alongside the notion of performativity.

Ottosson also seems to avoid the actual concepts of gender, sexuality, race and indigeneity when discussing men and masculinity in Aboriginal culture. It would have strengthened her theoretical discussion if she had reflected on these conceptual choices further, especially since critique of power and political rhetoric is (apparently) not a main feature in the music culture she is describing. Theoretical discussions of gender and music - not only in terms of performativity - are present in contemporary ethnomusicology (for example Chuse, 2013) and 
common in popular music studies (see Leonard 2007), discussions are furthered by full conferences, such as Music, Gender and Difference (Vienna, 10-12 October 2013), or Gender and Music: Practices, Performances, Politics (Örebro, 16-18 March 2016). Thus, there is a body of work on music, gender and sexuality that, at times, also includes questions about race and ethnicity, where Ottosson could have found theoretical advancements.

While the ethnographic chapters are well written, delightful to read and highly interesting for any music scholar wanting to learn more about central Australian musics, a more explicit theoretical framework could have strengthened the political, empirical and theoretical contribution of this publication. If popular musics in practice shape cultures of gender and indigeneity, then how are these cultures structured in terms of power? How does racism and sexism take place in this context? What is the relationship between (Australian) discourse and musical experience? In an ethnographic study focused upon the formation of contemporary aboriginal men, such questions should be embedded within the research, rather than pushed to the side in favour of descriptive writing.

\section{References}

Butler, J. 1990. Gender Trouble: Feminism and the Subversion of Identity. New York: Routledge.

Butler, J. 1993. Bodies That Matter: On the Discursive Limits of "Sex". New York: Routledge.

Chuse, L. 2003. The Cantaoras: Music, Gender, and Identity in Flamenco Song. New York: Routledge.

Diamond, B. 2000. The Interpretation of Gender Issues in Musical Life Stories of Prince Edward Islanders. In P. Moisala and B. Diamond Eds. Music and Gender. Urbana \& Chicago: University of Illinois Press: 99-139.

Leonard, M. 2007. Gender in the Music Industry: Rock, Discourse and Girl Power. Aldershot: Ashgate.

Ramnarine, T.K. 2013. "In Our Foremothers' Arms": Goddesses, Feminism, and the Politics of Emotion in Sámi Songs. In F. Magowan and L. Wrazen Eds. Performing Gender, Place, and Emotion in Music: Global Perspectives. Rochester: University of Rochester Press: 162-184. 